\title{
Неінструментальні методи оцінки рівноваги у осіб із черепно-мозковою травмою
}

Крук Б. Р., Росолянка Н. Я.

Львівський державний університет фізичної культури, м. Львів, Україна

Актуальність. Черепно-мозкова травма (ЧМТ) являє собою складну як медичну, так і соціально-економічну проблему (J. Ghajar, 2000). Зниження працездатності та інвалідизація хворих є наслідком черепно-мозкової травми i трапляється у $50-100 \%$ випадків, залежно від важкості травми. Для перевірки ефективності фізичної терапії необхідні тести, які дають змогу оцінити здатність виконання повсякденних завдань, а також відобразити вплив неповносправності на загальний стан здоров'я і якості життя пацієнта (Яворская В. А., 2012; Живолупов С. А., 2009).

Мета дослідження: проаналізувати використання клінічних тестів для оцінки рівноваги в осіб із черепно-мозковою травмою.

Матеріали та методи: теоретичний аналіз і узагальнення даних науково-методичної літератури та інформаційної мережі Інтернет.

Результати дослідження та їх обговорення. Для оцінки важкості порушення рухових навичок, ефективності та результатів фізичної терапії необхідні тести, які дають можливість об'єктивно визначити рівень володіння руховими навичками та встановити чинники, які впливатимуть на загальний стан здоров'я і якості життя пацієнта (Wood-Dauphinee S., 1997; Живолупов С. А., 2009). Використання тестів для оцінки рів- новаги в процесі фізичної терапії є необхідним для формування цілей реабілітації. Для визначення рівноваги можемо застосовувати клінічні шкали, які виявляють наявність або відсутність порушень, визначають ризики падінь (шкала Берга, функціональне досягнення, тест чотирьох квадратів, проба Ромберга). Перелічені тести мають доведену надійність (Berg K., 1992; Hong S. K., 2015; Dite W., 2007; Blennerhassett J. M., 2008; Duncan P. W., 2017; Whitney S. L., 2007). $€$ простими і зручними у застосуванні.

Висновки. Існує низка тестів, які можуть бути використані як достовірні та ефективні клінічні тести для оцінювання рівноваги й координації рухів у хворих із неврологічними розладами, зокрема для осіб із забоєм головного мозку. Їх доцільно використовувати для оцінки важкості рухових порушень, ризиків падіння та динаміки результатів реабілітації.

Перспективи подальших досліджень будуть пов'язані з використанням клінічних тестів для оцінки стану рівноваги та координації рухів у осіб із забоєм головного мозку в лікарняному періоді реабілітації.

Ключові слова: клінічні тести, методи дослідження, фізична терапія, забій головного мозку, фізичні вправи.

Список літератури: знаходиться в редакції (прим. ред.) 